\title{
A Brief Reply to Professor Cassell
}

\author{
Marvin Zalman*
}

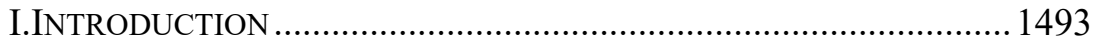

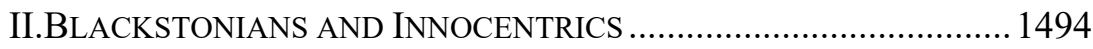

III.A BRIEF AND PARTIAL REPLY TO SOME OF PROFESSOR CASSELL'S

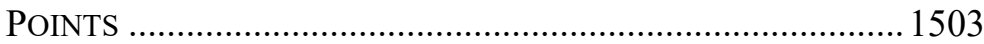

A. Trade-offs Are Inevitable ............................................ 1503

B. Abolishing the Fourth Amendment Exclusionary Rule 1504

C. The "Freeing Up Time" Argument.................................1506

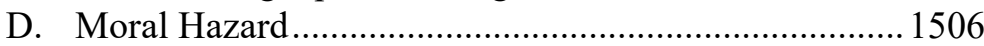

E. Replacing Miranda Rules with Videotaping of Custodial Interrogations........................................................... 1507

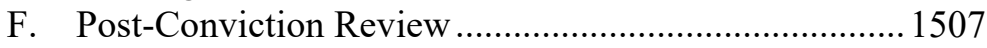

G. Requiring Defense Attorneys to Directly Ask Their Clients

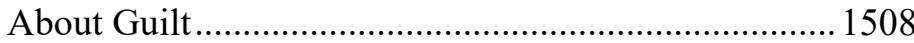

H. Increasing Defense Lawyer Resources....................... 1509

I. More Research and Dry Wells...................................... 1510

IV.WEIGHING COSTS OF WRONGFUL CONVICTIONS.......................1511

A. The Parole Extension Proposal ........................................ 1511

V.WHY Is THIS SUBJECT IMPORTANT?......................................... 1512

\section{INTRODUCTION}

In my article, The Anti-Blackstonians, ${ }^{1}$ I expanded my role as a responder to Dr. Laudan's paper ${ }^{2}$ by adding criticisms of other authors whose ideas, in my view, would not advance the goal of reducing wrongful convictions nor improve the criminal justice system. ${ }^{3}$ My truncated critique

* Professor, Criminal Justice Department, Wayne State University.

1 Marvin Zalman, The Anti-Blackstonians (Sept. 9, 2017) (draft manuscript) (on file with author). To read the updated, published version of this article, see Marvin Zalman, The Anti-Blackstonians, 48 Seton Hall L. ReV. 1319 (2018).

2 Larry Laudan, Different Strokes for Different Folks: Fixing the Error Patterns in Criminal Prosecutions by 'Empiricizing' the Rules of Criminal Law and Taking False Acquittals Seriously, 48 SeTON Hall L. Rev. 1243 (2018).

3 This included Daniel Epps, The Consequences of Error in Criminal Justice, 128 HARV. L. REV. 1065 (2015). 
of an article and chapter by Professor Paul Cassell invited a response; ${ }^{4}$ he rose to the challenge and joined the Symposium in his essay which responds primarily to Dr. Larry Laudan's essay and my comments. ${ }^{5}$ My brief reply here will not fully canvass all the issues raised in his response; it is intended to clarify for readers a few issues raised by Professor Cassell, while perhaps leaving some stones to be turned over at a later time and place. In this brief reply, I will: in Part II, address Professor Cassell's views on my supposedly half-hearted innocentrism and the question of ideological predilections in legal scholarship; in Part III, make a few comments about Professor Cassell's reply to my critique of his article and chapter; in Part IV, make a few comments about Professor Cassell's expansion on Professor Laudan's ideas; and in Part V, conclude.

\section{BLACKSTONIANS AND INNOCENTRICS}

Although I disagree with Professor Cassell on most points (and tentatively agree on others in principle) his comments helped me clarify intended meanings that were vague or implied in my Anti-Blackstonians article. I begin with his characterization of my review as an ad hominem attack, ${ }^{6}$ which according to Professor Cassell, characterizes him as ideologically driven, while as he put it, I, presumably, am not. ${ }^{7}$ I simply meant to contrast our apparent ideological preferences as conservative (his) and liberal (mine). Buried in my article is my view that every person necessarily "carries" an ideology or political preference, ${ }^{8}$ and in the conclusion I attempted to explain that my "nonepistemic" support for the Blackstone principle rests on "my values [which] lead me to fear abuses of state power more than criminal harms." I can see where this statement of my ideological position may have been too subtle to be detected and got lost in the shuffle, especially as I did not use the dreaded "L" word. I will use

4 See Paul G. Cassell, Freeing the Guilty Without Protecting the Innocent: Some Skeptical Observations on Proposed New “Innocence” Procedures, 56 N.Y.L. ScH. L. REV. 1063 (2012) [hereinafter Cassell, Freeing the Guilty]; Paul G. Cassell, Can We Protect the Innocent Without Freeing the Guilty? Thoughts on Innocence Reforms That Avoid Harmful Tradeoffs, in Wrongful CONVICTIONS AND THE DNA REVOlution: TwENTY-FIVE YeARS OF FreEING THE INNOCENT 264-90 (Daniel S. Medwed ed., 2017) [hereinafter Cassell, Can We Protect the Innocent].

5 Paul G. Cassell, Tradeoffs Between Wrongful Convictions and Wrongful Acquittals: Analyzing the Risks and Avoiding the Risks, 48 SETON Hall L. Rev. 1435 (2018) [hereinafter Cassell, Tradeoffs].

6 Id. at 1467 n. $141,31$.

7 Id. at 1472; I quoted from a news account of his efforts to bring a Miranda challenge before the Supreme Court. See Zalman, supra note 1, at 1393 n.385 (quoting Roger Parloff, Miranda on the Hot Seat, N.Y. Times (Sept. 26, 1999), http://www.nytimes.com/1999/09/26/ magazine/miranda-on-the-hot-seat.html).

8 Zalman, supra note 1, at 1366 n.253. 
this reply in part as a prequel to my article.

To be human is to have cognitive biases and predilections. ${ }^{9}$ Among those, we all carry political preferences, which social scientists label "ideologies." Ideology is a loaded word which connotes many things, often negative, but cannot be avoided. Political scientist Judith Shklar ran into a buzz saw of criticism when she offered the view that lawyers have a professional ideology, "legalism"- "the ethical attitude that holds moral conduct to be a matter of rule following." 10 Ideologies can include the familiar left-right spectrum of viewing other people as more or less like "us" so that "we" are more or less willing to share our goods with them. Another ideological spectrum is comfort with state power, from statist (whether on the left or right) to the anti-statist ideologies of anarchy on the left or libertarianism on the right. ${ }^{11}$ Other ideological vectors exist so that applying a simple label to a writer (e.g., "liberal"; "conservative") misses a lot of nuance. Having an ideological predisposition does not necessarily drive a person to blindly follow an "ideologically correct" position. Some ideologies are extreme; others are moderate. Some people become "ideologues," while others have leanings that they can set aside to a degree when conducting scientific, legal, or other professional work, or simply living their lives.

It seems to me that we miss a lot of what is important to know if we try to think about criminal justice, Supreme Court criminal procedure rulings, and ideas like the Blackstone principle without considering ideological frames. One of the most valuable such frames for criminal justice analysis is Herbert Packer's "two models" which identified the conflicting ideals and ideas of justices and scholars in the 1960s when the Court was erecting modern criminal procedure. Packer's approach encompasses a kind of a conservative-liberal continuum but in terms that capture the more specific concerns of constitutional lawyers. ${ }^{12}$ The "crime control" and "due process" models have had resonance as applied to criminal justice more broadly. ${ }^{13}$ Packer also wisely and correctly included broad areas of agreement among "due process" or "crime control" adherents.

9 Daniel Kahneman, Thinking, Fast and Slow (2011).

10 Judith N. ShKlar, Legalism: Law, Morals, and Political Trials 1 (reprint ed., Harvard Univ. Press 1986).

11 Kenneth R. Hoover, IdeOlogy and Political Life (2d ed. 1994).

12 Herbert L. Packer, Two Models of the Criminal Process, 113 U. PA. L. ReV. 1 (1964); Herbert L. Packer, The Limits of the Criminal SAnCtion 149-246 (Stanford Univ. Press 1968). In addition to sketching differences between "crime control model" and "due process model" adherents, it is worth recalling that Packer identified areas of agreement between the two models.

13 Hadar Aviram, Packer in Context: Formalism and Fairness in the Due Process Model, 36 LAW \& SOC. INQUIRY 237 (2011). 
From this perspective, I write as, among other things, a criminal justice social scientist/legal scholar who carries a (more or less) liberal or "due process model" perspective. It may be impossible to be entirely aware of one's cognitive biases or political leanings, but to deny that they exist seems foolish and may weaken readers' abilities to fully comprehend an author's message. ${ }^{14}$ Such awareness is only a starting point for legal or social scholars and for social scientists. The legitimacy of their work is measured by their adherence to the canons of scholarship or the quality of their data collection and analytic strategies. The anti-Blackstonians I critique write mainly in abstract terms, and Laudan and Allen even provide a mathematical proof. Professor Daniel Epps does allow that "one's intuitions here will also depend on underlying views about the relationship between the state and its citizens," 15 and at points, Laudan and Allen express some displeasure with scholars who they view as insensitive to the suffering of serious crime victims, perhaps a muted criticism of liberals. Awareness of one's leanings can help explain why a scholar is drawn to certain subjects and why conclusions not dictated by scientific findings, as is often the case in jurisprudence, go in one direction or the other. ${ }^{16}$ Were it otherwise, five-tofour rulings by the Supreme Court, accepted by constitutionalists as expressions of acceptable but contested views about conflicting ideals, would be viewed as beyond the pale of reason.

One's ideology is not easily changed as it "arises in the course of common social experiences" and thus, in a sense, binds one to a collectivity. ${ }^{17}$ Shklar subtly hints that her "ideological contribution,"-a "barebones liberalism"-is a "defense of social diversity" and pluralism, which is "common among members of permanent social minority groups." 18 Although the works reviewed in The Anti-Blackstonians were written in abstract, theoretical, and formal terms, ${ }^{19}$ it makes sense to explore anti-

14 My model is Shklar, see supra note 10, who linked her views on the legitimacy of the Nuremberg War Crimes Trial to the reasons for her attachment to a "barebones liberalism" of social diversity; this attachment, however, is not her argument, which unfolded in a complex and valuable political theoretic and jurisprudential analysis.

15 See Zalman, supra note 1, at 107, n.535 (quoting Daniel Epps, The Consequences of Error in Criminal Justice, 128 HARV. L. REV. 1065, 1138 (2015)).

16 Natural scientists, of course, also engage in disputes over the accuracy and interpretations of findings.

17 SHKLAR, supra note 10 , at 5.

18 SHKLAR, supra note 10, at 5-6. I have pondered this formulation for a long time and have taken it personally as a first-generation American citizen whose parents escaped the Holocaust and arrived in the United States after the Second World War had begun. However, this personal take may only reflect how an individual evaluates his or her experiences in a historical context, thus suggesting that within-group ideological variation could have a genetic basis. See Robert A. Burton, On Being Certain: Believing You Are Right Even When YOU'RE NOT 102-23 (2008).

19 In fairness, this applies more to Epps and Laudan and Allen than to Cassell, although 
Blackstonianism, to a degree, as a cluster of predilections which, because they affect law and criminal justice policy, fit into a more-or-less "crime control model" ideology. ${ }^{20}$

Professor Cassell protests his inclusion as an anti-Blackstonian, and at various points, tries to position me as not a true "innocentric." As to the first point, I explained the basis for my grouping of Epps, Laudan and Allen, and Cassell in the article. Epps defines himself as an anti-Blackstonian in preferring a theoretically neutral criminal procedure. Laudan and Allen's formal adherence to Blackstonianism rests mostly on the concern with a wrongful conviction also being a false negative (i.e., a "wrongful acquittal") in wrong person cases, while Cassell seems to claim near perfection in that his trade-off proposals would almost always convict the guilty and acquit the innocent. But I do not accept Laudan and Allen's and Cassell's versions of Blackstonianism as the genuine article. I wrote:

The overall direction of Cassell's proposals would reduce defendants' procedural protections. I have no doubt that Laudan and Cassell genuinely grieve over false convictions. However, although they claim adherence to a variation of the Blackstone ratio (in Laudan's case) or the Blackstone principle (in Cassell's case), I count them as anti-Blackstonians because despite their claims their programs would (1) seriously weaken defendants' rights, (2) not reduce wrongful convictions, and (3) not enhance public safety. ${ }^{21}$

What is of interest is Professor Cassell's definition of innocentrism as a mode of thought that cares only about reducing wrongful convictions to the exclusion of other policies (except for trade-offs that increase crime) and his insistence that a scholar who claims to write from an innocentric position must adhere to it, to the exclusion of other ideas. ${ }^{22}$

in Tradeoffs, supra note 5, at 1435, he takes up Laudan's analytic approach with relish.

20 Supreme Court opinions can be written in the most abstract terms that never deviate from legal form, and yet, when examined by political scientists, are seen to align with the politics of the appointing President. See LAWRENCE BAUM, IDEOLOGY IN THE SUPREME COURT (Princeton Univ. Press 2017).

21 Zalman, supra note 1, at 1327 n.15.

22 Although this is the gist of his critique of my positions, it goes against his third criterion for how an "innocentric" might proceed; by (1) asking if a proposal reduces wrongful convictions, (2) weighing any costs of increasing crime by releasing the guilty, and (3) asking if any competing values "such as constitutional requirements ... clearly outweigh the presumption in favor of proposal (sic) that would otherwise protect the innocent." See Cassell, Tradeoffs, supra note 5, at 1346. A weakening of constitutional restraints on the government's penal authority is such a competing value. 
The need to explain to myself my adherence to this vision of the Blackstone principle led me at the conclusion of The Anti-Blackstonians to admit that if push comes to shove I will accept the possibility of some guilty going free to maintain a criminal procedure that strengthens civil liberty by limiting the exercise of undue state power. This civil rights orientation is an expression of my liberalism. However, the bulk of my analysis argues that the anti-Blackstonians are wrong in most respects in their assessments of trade-offs. Epps's empirical justifications are far too thin to support his argument. ${ }^{23}$ Laudan's analysis is almost entirely ignorant of incapacitation analysis and his proposals, in addition to trashing constitutional rights wholesale, would likely increase crime and misery if adopted. ${ }^{24}$ Cassell's proposals, despite his assertions, would do little or nothing to reduce wrongful convictions, a position I advanced in my article in this Symposium. ${ }^{25}$

Professor Dan Medwed coined the term "innocentrism," which stands, to a degree, outside the defense attorney ethic of not caring about guilt or innocence, but valorizes policies that improve criminal justice diagnosticity. Innocentrism makes sense only (or mostly) in the context of the modern innocence movement, which has the dual goal of exonerating factually innocent clients and establishing policies that tend to reduce wrongful convictions. The latter goal includes improving the accuracy of police work, forensic science analysis, and prosecution decisions. Reforms that accomplish these ends will not only tend to reduce wrongful convictions but will make the (accurate) conviction of serious criminals more likely. ${ }^{26}$ Thus, innocentrism may discomfort some liberal legal scholars or defense attorneys who would support only accuracy reforms that favor defendants. ${ }^{27}$ Toward the end of Professor Medwed's article, writing to defenders, he does not pose innocentrism as an exclusive ideology: "What criticisms from the left occasionally appear to lack is an appreciation for innocentrism as a

23 Zalman, supra note 1, at Part III.A.

24 Zalman, supra note 1, at Part III.B.

25 See Zalman, supra note 1, at Part III.C. I will add a few brief comments regarding my critique of Professor Cassell's article and chapter in Part II below in response to his reply, but I have no desire to expand my Reply into a full-blown reiteration of my positions in The AntiBlackstonians or engage in a continuing debate in this venue.

26 Laudan and Cassell put possible trade-offs at the front of their analysis. My short conclusion is that trade-offs are theoretically possible and surely do occur; that Laudan's analysis of trade-offs is hypothetical and based on a significant misunderstanding of the criminal justice process; that Cassell's are either wrong or short of the mark (see part (2)), and that in the real world of agency practice and resource allocation and legislative policy making, innocentric reform proposals will be subjected to close analysis and withering criticism and will usually be rejected or if passed held to the most minimal terms.

27 See, e.g., Robert P. Mosteller, Protecting the Innocent: Part of the Solution for Inadequate Funding for Defenders, Not a Panacea for Targeting Justice, 75 Mo. L. REV. 931 (2010). 
corollary to-not a replacement for-traditional defense theories; innocentrism simply provides another powerful tool in the strategic woodshed." ${ }^{28}$ Professor Medwed might not be a true innocentric in Professor Cassell's view, although some thought can be given to whether innocentrism applies equally to "innocence lawyering" 29 as to innocence reform.

As I noted, Professor Cassell takes me to task at several points for not being a thoroughgoing innocentric along the lines he lays down. This is odd as his third criterion for how "an innocentric might proceed in evaluating a reform proposal" is: "Do any competing values - such as constitutional requirements or other concerns - clearly outweigh the presumption in favor of proposal that would otherwise protect the innocent." 30 As I have already stated, my liberal values, born of a sense of being, in Shklar's terms, the member of a permanent social minority group, leads me to favor limits on the state's penal apparatus that could threaten (my) civil liberties. But given the complexity of academic writing that can obscure or complicate the ideological roots of an author's thinking, it is helpful to qualify many statements in the spirit of "more or less." I might be more willing than a Medwed or a Mosteller, among the defense-leaning innocentric scholars, to favor policies that make the prosecutor more proficient; likewise, Cassell may advocate positions that hide-bound prosecutors would oppose as too "liberal." 31 Nevertheless, in my estimation, most of Professor Cassell's proposals made in the article and chapter that I reviewed, will not reduce wrongful convictions; I reject them on empirical or epistemic grounds, and if they hold the seeds of weakening constitutional protections, I reject them under his criterion number three (i.e., non-epistemic grounds).

Having come out of the ideological closet as a liberal (of sorts), ${ }^{32} \mathrm{I}$ briefly explain my innocentrism. Professor Cassell labels me an innocentric and defines it rigidly, but does not quite get the gist of my self-definition. What I wrote was: "As a self-defined innocence scholar, I analyze the works

28 Daniel S. Medwed, Innocentrism, 2008 U. ILL. L. REv. 1549, 1566 (2008). Professor Cassell may have been writing too fast to notice this when he wrote "Medwed never addressed what to do if the values associated with innocentrism conflicted with other values." Cassell, Tradeoffs, supra note 5, at 1466.

29 See D. Michael Risinger \& Lesley C. Risinger, The Emerging Role of Innocence Lawyer and the Need for Role-Differentiated Standards of Professional Conduct, in CONTROVERSies In InNOCEnCE CASES IN AMERICA 123-38 (Sarah Lucy Cooper ed., 2014).

30 Cassell, Tradeoffs, supra note 5, at 1466.

31 In his reply, Cassell notes that he has opposed mandatory minimum sentences and favored strengthening a defendant's double jeopardy protections and other liberal positions. See Cassell, Tradeoffs, supra note 5, at 1467.

32 E.g., I believe that punishment theory needs to include a retributive base, although I favor the mildest punishments that are feasible to achieve several criminal justice and societal goals. From this heterodox, or perhaps idiosyncratic posture, I infer that every person (and writer) exhibits ideological variations of ideas that limit the precision of general labels. 
of Epps, Laudan and Allen, and Cassell from an "innocentric" perspective." 33 I am first a criminal justice scholar, with a grounding in law and social science, who has since 2005 studied the innocence movement and written about wrongful conviction in both legal and scientific journals. ${ }^{34}$ I placed my identification with innocentrism in scare quotes, which implies an agreement with Professors Medwed's and Findley's analyses that differentiates innocence policy from the kinds of policy stances associated with the criminal defense bar. Innocentrism is not some kind of sect that requires my suspension of disbelief in evaluating ideas, whatever their source. The relatively new social science of criminal justice engages in peerreviewed research that explores the way in which many elements of criminal justice operate; where deficiencies (functional and normative) occur, reforms are advocated. ${ }^{35}$ From this role orientation and my ideological position, I value several (possibly competing) goals: fewer wrongful convictions; greater ability to accurately identify and prosecute serious crimes; impose the least harmful punishments needed to achieve a safe society; effective government and social welfare policies that either are designed to reduce crime or will have crime-reducing effects; non-violation of constitutional or human rights by law enforcement. There are trade-offs and hidden costs to all such goals. Resources are always scarce and the competitive policy process does not always generate the most rational policies. Cost-benefit analysis is one potentially beneficial tool of policy analysis among others, although the technique has its own limits and hidden costs. ${ }^{36}$ Thus, while trade-offs between some of these goals surely exist, and while analysis is needed even if not perfect, my general view is that innocence (or innocentric) reforms proposed to date, do not have a crime enhancing effect.

With these generalities in place, my analysis of the anti-Blackstonians from my "innocentric perspective" simply indicates a leaning that favors criminal justice policies that strengthen the ability of police, forensic science

33 Zalman, supra note 1, at Part III.B.

34 I do not practice law; I have been formally retired from the New York Bar for many years, and earned a Ph.D. in Criminal Justice from the State University of New York in 1977.

35 The discipline of criminal justice as a social science arguably emerged from federal funding that began in the 1970s and includes the policy-oriented work of criminologists. In recent years, the quality of crime and policy research has risen considerably, as can be seen by publications in such journals as Justice Quarterly, Criminology, Criminal Justice Policy Review and Criminology \& Public Policy.

36 Darryl K. Brown, Cost-Benefit Analysis in Criminal Law, 92 CAL. L. REv. 323 (2004). See also 4 CRIMINOlogy \& PUB. POL'y (Nov. 2005), https://onlinelibrary.wiley.com/toc/ 17459133/4/4 (consisting of an editorial introduction, a research article, and five commentaries, and exploring the "role of the cost-of-crime literature"). That issue raises several concerns and criticisms of the methodologies employed and the omission of considerations of equity and fairness in some cost-of-crime estimates that undergird costbenefit analyses of criminal justice policies. 
and prosecution to detect and convict guilty parties even if some in the defense attorney camp would not. And if the conclusion to my articleplacing the value of limiting excessive governmental power in criminal justice above crime control if necessary (although measuring both categories is not easy) - is not truly innocentric in Professor Cassell's eyes, so be it. But I thank him for helping me to clarify my position. Whatever my position ("innocentrism plus"?), it does not mean that I have to believe in Professor Cassell's assertions. ${ }^{37}$

This leaves the question of whether Professor Cassell's approach can legitimately be seen to fit into Packer's "crime control" model, labeled "conservative" for convenience, with all the qualifications that a simple label cannot fully encompass the work of a mature scholar. He seems to have none of it. He writes that I try "to undercut [his] proposals by leveling the ad hominem attack that they 'derive from a conservative, crime control model vision' of criminal justice." He has a point when he wrote (in our earlier exchange) that I do not support this assertion. I thus amend my (earlier) reply. I base my assertion on the famous work of Professor Cassell and attorney, now Justice, Stephen Markman, ${ }^{38}$ which vigorously attacked the work of Hugo Bedau and Michael Radelet, who claimed that a number of twentieth century death sentences were handed down against innocent defendants. $^{39}$ In their reply to the Bedau-Radelet study, Markman and Cassell asserted their belief that "the risk [of sentencing innocent defendants to death] is insignificant, in the sense that it is statistically minuscule and also in the sense that it does not affect the validity of our society's considered judgment that the benefits of capital punishment outweigh the costs." 40 As for his recent article and chapter on wrongful conviction, which was the focus of my criticism, he takes positions to eliminate the Fourth Amendment exclusionary rule and abolish the Miranda rule. These are famously identified as conservative/crime control policies. As I noted in The AntiBlackstonians, they were key components of the Truth in Criminal Justice series of articles that emanated under Justice Markman's direction in the Attorney Generalship of Edwin Meese in the Presidency of Ronald Reagan. ${ }^{41}$

37 Professor Cassell seems genuinely surprised that I do not join his purportedly innocentric ideas and chalks my opposition up to my adoption of "competing values." See Cassell, supra note 5, at 1466.

38 See Stephen J. Markman \& Paul G. Cassell, Protecting the Innocent: A Response to the Bedau-Radelet Study, 41 StAN. L. ReV. 121(1988). I began my analysis of Professor Cassell's article and chapter on innocence issues with a sketch of this early work by Markman and Cassel. At present, Markman is a justice of the Michigan Supreme Court.

39 Hugo Adam Bedau \& Michael L. Radelet, Miscarriages of Justice in Potentially Capital Cases, 40 Stan. L. Rev. 21 (1987).

40 Stephen J. Markman \& Paul G. Cassell, Protecting the Innocent: A Response to the Bedau-Radelet Study, 41 StAN. L. ReV. 121, 122, n.3 (1988).

41 Zalman, supra note 1, at Part III.C. In a lengthy footnote, Professor Cassell points to 
If Professor Cassell's position does not reflect a conservative/crime control ideology of criminal procedure, then I do not know what does.

Yet, in our exchange, Professor Cassell provides evidence of his work as a scholar and decisions as jurist that supports defendants' rights. ${ }^{42}$ Such variation supports an important and often overlooked feature of Packer's two-model analysis, namely that there are significant areas of agreement among proponents of the two models. Further, within the area of constitutional criminal procedure there are a number of cases in which jurists who undoubtedly have general ideological predilections have written opinions, whether for doctrinal or prudential reasons, appear to not be aligned with the judge's "typical" orientation. ${ }^{43}$ Such variations reflect the reality that legal reasoning in general involves complex intellectual exercises requiring the application of elastic modes of jurisprudential thinking to variable fact situations. In these undertakings, while ideological predilections generally align with direction of authors' writings, scholars and judges (at least in non-autocratic polities) retain such intellectual independence and integrity so that their decisions and writings do not adhere to a "party-line." My own evaluation of Professor Cassell's articles on issues related to broad issues of innocence is that they reflect a degree of "innocence skepticism" that goes beyond valuable corrections to the risk of justice system errors that release factually guilty defendants or errors in innocence work, ${ }^{44}$ and make erroneous conclusions that are driven by a

several academic and judicial positions he has taken that present as "liberal." As indicated, I do not assert that ideological predilections are necessary monolithic, and for most scientists and academics, predilections tend to be muted or complicated, but it seems foolish to me to deny their existence.

42 See Cassell, Tradeoffs, supra note 5, at 1467 n.141.

43 E.g., Chief Justice Warren's majority opinion in Terry v. Ohio, 392 U.S. 1 (1968); Justice Brennan's majority opinion in Schmerber v. California, 384 U.S. 757 (1966); Justice Scalia's majority opinion in Arizona v. Hicks, 480 U.S. 321 (1987); and Justice O'Connor's dissenting opinion in Illinois v. Krull, 480 U.S. 340 (1987).

44 The innocence movement does not deny that errors can be made by those who work to exonerate the wrongfully convicted. In the well-attested case of Roger Coleman, postexecution DNA analysis connected him to the rape-murder for which he was executed. To the great credit of James McCloskey, director of Centurion Ministries who worked to clear Coleman, as soon at the truth was known, McCloskey issued a candid press release acknowledging his error and the vital importance of seeking the truth. See Press Release, James C. McCloskey, Exec. Dir., Centurion Ministries, Inc., On the Roger Coleman DNA Testing Results (Jan. 12, 2006), http://centurion.org/_faq/coleman-roger-press-release.pdf. Another troubling case in which an exoneration is questionable is that of Anthony Porter, which Cassell identified in his article. See Cassell, Tradeoffs, supra note 5, at $10 \mathrm{n} .57$. These examples indicate that all criminal case analyses are subject to error. Innocence organizations, however, routinely screen out requests for assistance from prisoners who do not appear to be innocent. See Gwendolyn Carroll, Proven Guilty: An Examination of the Penalty-Free World of Post-Conviction Testing, 97 J. CRIM. L. \& CRIMINOLOGY 665 (2007). The National Registry of Exonerations welcomes any information regarding the exonerations it posts and stands willing to reconsider its conclusions. 
more-or-less conservative, crime control orientation.

\section{A BRIEF AND PARTIAL REPLY TO SOME OF PROFESSOR CASSELL'S POINTS}

Professor Cassell's reply article necessarily reprises some of his arguments in his prior article and chapter. ${ }^{45} \mathrm{I}$ don't intent to engage in a full scale development of any counter-arguments or repeat the critique in my main article. His rather lengthy reply seems to dare me to come out of hiding and enter an extended (and perhaps continuing) debate on his counter- points. For the most part, I rest my arguments on what I wrote in The AntiBlackstonians, but I will add or emphasize a few points

\section{A. Trade-offs Are Inevitable}

No one can rationally disagree that efforts to decrease wrongful conviction might in some cases allow the guilty to escape, or, conversely, that the large-scale enterprise to enforce the law and convict the guilty routinely generates wrongful convictions. Innocence lawyers (and prosecutor's offices' conviction integrity units) focus on the latter problem, while prosecutors are rightly concerned (acting within the bounds of law) to prevent the former in legal practice. When it comes to policy advocacy the innocence movement and aligned independent scholars (me included) focus on the latter issue. It is in the abstract a good thing that some scholars take what seems to be a minority position in the field of innocence scholarship and pose the question of whether innocence reforms might on balance do more harm than good. In the execution, however, I have a number of concerns with Professor Cassell's ideas, which led to my criticism in The Anti-Blackstonians.

Various proposed and enacted innocence reforms, which are only beginning to come on line, should be examined for possible unexpected consequences. But some of Professor Cassell's proposals for modifying the procedural landscape of criminal justice have been implemented and tested. Building on extant scholarship he claims that eliminating procedural challenges under the Fourth Amendment exclusionary rule and Miranda will free up defense attorney time to focus on factual issues, without allowing for additional resources $\left(\right.$ money $\left.^{46}\right)$ to reduce excessive caseloads and increase investigative services for defendants. I am skeptical that the expected time saving will result in more robust lawyering, and Professor Cassell's assertions do not make it so. However, in contrast to this hypothetical

\footnotetext{
45 Cassell, Freeing the Guilty, supra note 4; Cassell, Can We Protect the Innocent, supra note 4 .

46 Cassell, Tradeoffs, supra note 5, at 1485.
} 
improvement, historical analysis can support the thesis that the Supreme Court's watering down of constitutional protections since 1972 has enabled police and prosecutors to engage in "wars" on drugs crime that resulted in mass incarceration. Procedural rights minimization has not alone led to the socially dysfunctional expansion of the American correctional apparatus (i.e., mass incarceration), but it has been a contributing factor. ${ }^{47}$

Is this issue orthogonal to wrongful convictions? A hard-to-test hypothesis but one worthy of consideration is that the war on crime/drugs overwhelmed the criminal justice system with less serious cases that caused more false convictions and fewer accurate convictions than would otherwise have resulted. The mechanisms included the judicial attenuation of exclusionary rules that sapped defense lawyers' abilities to fight against expanded drug arrests and draconian penalties for drug crimes. Thus, not only has mass incarceration harmed America's economy and deepened racial animosities, but has diverted the attention and resources of law enforcement, forensic science (burdened with testing drugs), and prosecutors from addressing serious violent and property crimes. ${ }^{48}$

\section{B. Abolishing the Fourth Amendment Exclusionary Rule}

Professor Cassell's reply does not acknowledge that the exclusionary rule today, after two generations of evisceration by the Supreme Court, is a hollow shell of what was envisaged by Warren Court justices. Worse, from an innocentric perspective, he avoids the data I adduced showing that search and seizure practice, unrestrained by effective legal challenges, today allows the police to plant illegal evidence on innocent people, creating many wrongful convictions. ${ }^{49}$ I may have been too fast in dismissing out of hand some jurists' suggestion of yesteryear that the exclusionary rule be replaced by administrative control measures, ${ }^{50}$ dismissing them simply as rightsstripping stalking horses. I assume that such proposals were made in good faith. Indeed, based in part on research, I support administrative measures as being more effective in shaping the law-following behavior of police than

47 See Ernest Drucker, A Plague of Prisons: The Epidemiology of Mass INCARCERATION IN AMERICA (New Press 2011). A packed bookcase of works on the ills of mass incarceration exists.

48 Hannah Laqueur et al., Wrongful Convictions, Policing, and the 'Wars on Crime and Drugs,' in Examining Wrongful Convictions: StepPing BaCk, Moving Forward 93-107 (Allison D. Redlich et al. eds., 2014).

49 More than 1800 "group exonerations" have been identified by the National Registry of Exonerations. See Samuel Gross et al., Race and Wrongful Convictions in the United States, NAT'L REgistRY OF EXONERATIONS, at 20-26 (Mar. 7, 2017), https://www.law.umich.edu/special/exoneration/documents/race_and_wrongful_convictions .pdf.

50 E.g., Chief Justice Burger's proposal in Stone v. Powell, 428 U.S. 465, 500-01 (Burger, C.J., concurring). 
the exclusionary rule. The exclusionary rule, however, remains useful as a legal backstop to enforce constitutional rights and a robust Fourth Amendment provides police officials with a reason to enact meaningful administrative rules. Where stakes are high, redundancy has value. Professor Cassell seems mired in past examples. I would suggest that he look into research supporting the benefits of devices like community review boards, early intervention models and federal consent decrees in his desire to ensure that police do not violate constitutional rights and are not under such lax procedures that that they feel free to corruptly plant incriminating evidence on innocent people. ${ }^{51}$ Such devices to ensure police lawabidingness should reduce the opportunities police have to use their search and seizure powers to create wrongful convictions.

I will add, without extended constitutional exegesis, that I believe that retaining the Fourth Amendment exclusionary rule and the Miranda exclusionary rule tends to restrain excessive police power and uphold the rule of law. My "search and seizure philosophy," derived in large measure from Professor Heffernan's analysis, is that the Fourth Amendment is incoherent without the exclusionary rule ${ }^{52}$ and that the four dissenters in Herring had the better argument. ${ }^{53}$ At some future point, I am confident that the Supreme Court, removed from the political fires that unduly politicized criminal procedure protections, ${ }^{54}$ will restore the rule and repair the damage to the Fourth Amendment. That said, this is not the place to reprise the huge doctrinal debate over Miranda and the exclusionary rule as Professor Cassell seems to be eager to do. My position is based on my legal perspectives on the Fourth Amendment exclusionary rule and Miranda, which, I believe fall within a range of accepted legal discourse. ${ }^{55}$ This position is not strongly supported by social science, as I seek to separate my policy desiderata from what can be supported by empirical research. The exclusionary rule may

51 Samuel Walker, The New World of Police Accountability (2005). Professor Cassell has forwarded a copy of a lengthy analysis that addresses police behavior; I pass on the reference shortly before our manuscript submission date, unread: Paul G. Cassell \& Richard Fowles, What Caused the 2016 Chicago Homicide Spike? An Empirical Examination of the "ACLU Effect" and the Role of Stop and Frisks in Preventing Gun Violence (undated) (unpublished manuscript) (on file with Paul G. Cassell).

52 William C. Heffernan, The Fourth Amendment Exclusionary Rule as a Constitutional Remedy, 88 GeO. L.J. 799 (2000); see also Thomas Y. Davies, Recovering the Original Fourth Amendment, 98 Mich. L. REV. 547 (1999).

53 Herring v. United States, 555 U.S. 135 (2009).

54 Louis M. Kohlmeier JR., God SAVE This HonOrable Court! (1972).

55 In this area of law, I am not sure if it is entirely possible to write from a purely disinterested or "umpireal" perspective, so when writing about constitutional criminal procedure, I also write as a citizen who remembers the McCarthy era with its attendant blacklists, and who desires the protections that the law offers to him and his family from undue government intrusion. See SAmuel Walker, The Rights Revolution: Rights and COMmunity In Modern America (Oxford Univ. Press 1998). 
have no measurable empirical restraining effect on actual police behavior but it is quite plausible that its ethical principles inspired police leaders to make constitutional policing a hallmark of their leadership, as it has with William Bratton. ${ }^{56}$ While it is empirically impossible to directly prove the effect of the exclusionary rule (in that it requires proving a negative), empirical research supports the idea that where police chiefs encourage constitutional policing, the rank and file are more likely to comply with the Constitution. ${ }^{57}$ On this basis (less than robust proof), my values lead me to argue that the constitutional protections Professor Cassell would eliminate are worth saving. ${ }^{58}$

\section{The "Freeing Up Time" Argument}

Professor Cassell argues at some length that stripping rights will free up time for defense attorneys to pursue actual innocence. This idea has been advanced by estimable scholars. But, it is only a hypothesis. There is no empirical evidence I know of to support this theory. The hypothesis seems facially implausible when considering the widely acknowledged scarce investigation resources available to indigent defenders and a sense of how much time practicing trial attorneys devote to brief writing (and acknowledging the widespread existence of "canned briefs") compared to plea bargaining. To borrow from my critique of Professor Epps, a theoretical proposal that seem specious on its face is too thin a reed on which to propose stripping rights from defendants.

\section{Moral Hazard}

But Professor Cassell's proposals may have a darker side. Early in his reply, he proposes that giving police greater power to search will provide them with "the functional equivalent of a crystal ball" to ascertain the ground truth in cases. ${ }^{59}$ He would make it constitutional by placing convicted defendants on extended ten-year parole. In Cassell's world, police appear to be incorruptible and he seems oblivious to the moral hazard that expanded search power is an opportunity to expand police corruption. ${ }^{60}$ I might add that Professor Cassell's proposal would require a massive increase to the correctional bureaucracies of states at a time the growing conservative push

56 William Bratton \& Peter Knobler, Turnaround: How America's Top Cop REVERSED THE CRIME EPIDEMIC (1998).

57 Bradley C. Canon, Testing the Effectiveness of Civil Liberties Policies at the State and Federal Levels: The Case of the Exclusionary Rule, 5 AM. PoL. Q. 57 (1977), http://journals.sa gepub.com/doi/pdf/10.1177/1532673x7700500103.

58 I hold to this position especially in light of the empirically implausible idea that eliminating rights would free defense attorney time to search for evidence of clients' guilt.

59 Cassell, Tradeoffs, supra note 5, at 1439.

60 See Zalman, supra note 1, at Part III.B.3. 
against greater penal control is in part a concern about expanding governmental bureaucracies. ${ }^{61}$

\section{E. Replacing Miranda Rules with Videotaping of Custodial Interrogations}

Professor Cassell has assiduously attacked the Miranda decision throughout his career. ${ }^{62}$ He does valiantly support the video recording of interrogations as a means of improving the accuracy of interrogationgenerated admissions. Although this is a step in the right directions, it is becoming clear that video recording is not a panacea and that those truly concerned with methods of police questioning that is both less abusive, less likely to generate false confession and obtain more information from suspects needs to learn more about the investigative interview, a technique developed in England that police training companies are beginning to adopt. I made this point in The Anti-Blackstonians. ${ }^{63}$

\section{F. Post-Conviction Review}

Professor Cassell endorses Joseph Hoffman and Nancy King's proposal to abolish state prisoner habeas review "except for those who couple a constitutional claim with "clear and convincing proof of actual innocence." "64 Federal habeas requires exhaustion of state remedies and, when it results in exoneration, comes many years after the initial, costly, injustice. As Sam Gross and Robert Mosteller have explained, wrongful convictions are very hard to detect and scrimping on opportunities to allow review will consign more innocents to die in prison. That said, the costs of federal habeas review have been exhaustively analyzed by the scholars cited by Professor Cassell and others. ${ }^{65}$ I would prefer to maintain and even expand habeas, subject to expert and dispassionate cost-benefit analysis, but

61 Bruce Rauner, the Republican governor of Illinois, has been praised for his effective prison reduction program. Edith Brady-Lunny \& Ted Gest, Justice Success Story: How Illinois Cut Its Prison Population, The Crime Report, Ctr. ON MEdia Crime \& Just. (Jan. 29, 2018), https://thecrimereport.org/2018/01/29/justice-success-story-how-illinois-cut-its-priso n-population/.

62 Paul G. Cassell \& Richard Fowles, Still Handcuffing the Cops? A Review of Fifty Years of Empirical Evidence of Miranda's Harmful Effects on Law Enforcement, 97 B.U. L. REV. 685 (2017).

63 See sources in Zalman, supra note 1, at Part III.C.2.c. See also JAMES L. Trainum, How the Police Generate False Confessions: An Inside LoOK at the Interrogation Room (2016); Marvin Zalman, Laura Rubino \& Brad Smith, Beyond Police Compliance with Electronic Recording of Interrogation Legislation: Toward Error Reduction, CRIM. JUST. POL'Y REV. 1 (2017), http://journals.sagepub.com/doi/pdf/10.1177/0887403417718241.

64 Cassell, Tradeoffs, supra note 5, at 56; Joseph L. Hoffmann \& Nancy J. King, Rethinking the Federal Role in State Criminal Justice, 84 N.Y.U. L. REV. 791, 820 (2009).

65 John H. Blume et al., In Defense of Noncapital Habeas: A Response to Hoffman and King, 96 CORNELL L. REV. 4365 (2011). 
as a backstop to more robust state post-conviction review. An avenue that I did not address but is worthy of serious analysis is improved state level appellate and post-conviction review of convictions both for procedural error and factual error. ${ }^{66}$ The most innovative change along these lines is the North Carolina Innocence Inquiry Commission (NCIIC). Recent analyses of this institution indicate that it has come under prosecutorial criticism, could improve its procedures, but is deemed successful. ${ }^{67}$ States may be able to enact some benefits of the NCIIC model without establishing an agency. This important subject calls out for more legal and empirical analysis.

\section{G. Requiring Defense Attorneys to Directly Ask Their Clients About Guilt}

My original comments on this proposal were short and I will not add much, although in his reply, Professor Cassell raises a good deal of argumentation. Upon reading his reply, it struck me that Professor Cassell's proposal is underdeveloped and could be fleshed out by giving more consideration to the acute chapter on innocence lawyering by the Risingers ${ }^{68}$ and to Keith Findley's article-length thought experiment about tinkering with the roles of prosecutors and defense lawyers, ${ }^{69}$ both of which are cited by Professor Cassell but not considered in depth. I will admit that I am now not sure if Professor Cassell's proposal would in fact make defense lawyers "subservient" to prosecutors. In his reply, he would "require" defense lawyers to ask their clients about guilt or innocence. ${ }^{70}$ A rule to "require" compliance implies enforcement. What I did not see in Professor Cassell's reply is whether his proposal would pierce lawyer-client confidentiality and open the client's response to the court and the prosecution. If not, his words are all bluster. If so, his proposal is a radical departure from the adversary system that would indeed make defense lawyers subservient to prosecutors. In his proposal, Professor Cassell bemoans that defense lawyers are indifferent to their clients' innocence, and yet, this stance is a pillar of the adversary system. It is fair game to critique the adversary system and

66 See Keith A. Findley, Innocence Protection in the Appellate Process, 93 MARQUETTE L. REV. 591 (2009).

67 Warren D. Hynson, North Carolina Innocence Inquiry Commission: An Institutional Remedy for Actual Innocence and Wrongful Convictions, 38 N.C. CENT. L. REV. 142 (2016); Robert P. Mosteller, N.C. Innocence Inquiry Commission's First Decade: Impressive Successes and Lessons Learned, 94 N.C. L. REV. 1725 (2016).

68 Risinger \& Risinger, supra note 29, at 135.

69 Keith A. Findley, Adversarial Inquisitions: Rethinking the Search for the Truth, 56 N.Y.L. SCH. L. REV. 911 (2012).

70 "I proposed that we could reorient defense counsel by simply requiring them to ask their clients about the subject." Cassell, Tradeoffs, supra note 5, at 1479. 
propose alternatives, ${ }^{71}$ but to suggest that a critical element of the defense role be eliminated without considering its consequences is either an ignorant proposal, which is inconceivable in such an accomplished jurist as Professor Cassell, or a sly move to checkmate one's opponent. In my understanding, the greater good that supports that defense attorney's "immoral" indifference to factual guilt or innocence, ${ }^{72}$ is that it is virtually the only mechanism in the adversary system that puts the prosecutor to her proof. The voluminous contemporary literature on prosecutorial dominance over charging ${ }^{73}$ makes, in my mind, Professor Cassell's proposal dangerous if it were to be treated seriously.

\section{H. Increasing Defense Lawyer Resources}

Again, I will not add much. Resources can be increased by more money or by greater efficiencies, or both. I alluded in my article to studies that are beginning to get a handle on increasing the efficiency of public defenders, so that they can be more effective within the constraint of limited funds. As Professor Cassell opined, a robust defense, which I assume includes adequate investigative resources, is perhaps the most important way to prevent wrongful convictions. I hope that in future writings he explores the subject of efficiencies and providing investigative resources to the defense in greater depth. ${ }^{74}$

71 See Marvin Zalman \& Ralph Grunewald, Reinventing the Trial: The Innocence Revolution and Proposals to Modify the American Criminal Trial, 3 TEX. A\&M L. REV. 189 (2015).

72 Setting aside that ascertaining the ground truth is not always easy, see Mosteller, supra note 67.

73 See Zalman, supra note 1, at 1348-49 nn.147-53.

74 Professor Cassel pointed out that in an op-ed article with former federal judge Nancy Gertner, they criticized Congress for cutting funding for the federal defenders' service. Paul Cassell \& Nancy Gertner, Public Defenders Fall to the Sequester, Wall ST. J. (Aug. 20, 2013), https://www.wsj.com/articles/public-defenders-fall-to-the-sequester-1377039667. I was not aware of this and am heartened by this stance. 


\section{More Research and Dry Wells ${ }^{75}$}

As indicated in my article, I think that his effort to ascertain the "true" number of wrongful convictions will not add much to current knowledge. ${ }^{76}$ As scholars are learning, the innocence movement is becoming an exoneration movement, ${ }^{77}$ and as Sam Gross has argued, exonerations are our best proxy for wrongful convictions, with all the gaps of knowledge that are inevitable. The fundamental limit of the kind of study proposed by Professor Cassell is the ground-truth problem. In my maiden article on wrongful conviction, I had the temerity to challenge Barry Scheck and Peter Neufeld's proposal to treat exonerations as the National Transportation Safety Board treats airplane crashes on the grounds that reconstructing a case (which amounts to retrying it) is not the same as analyzing the pieces of a downed airliner, black box and all. ${ }^{78}$

Another problematic aspect of Professor Cassell's proposal is site selection. As for dry wells, by definition, Professor Risinger's study of murder-rape death penalty exonerations was not a dry well because his ratio was based on a known denominator drawn from a national universe of cases, a rare and instructive phenomenon. ${ }^{79}$ Substructuring of wrongful conviction can be thought to apply geographically or jurisdictionally. ${ }^{80}$ Thus, an arduous Cassellean study of the number of wrongful convictions in Utah finding (let us say) a minuscule number would, I assume, be due to the high levels of professionalism and probity in that estimable state, but would miss the possibility that the wrongful conviction rate is very high in neighboring Nevada, which might just be a sinkhole of criminal justice incompetence and corruption. As the National Registry of Exonerations dryly reports, the number of exonerations "may not reflect the frequency of false conviction

75 Cassell, Tradeoffs, supra note 5, at 1489-90.

76 Zalman, supra note 1, at Part III.C.2.a. As noted, just as we were finishing our comments, Professor Cassell forwarded a manuscript. Paul G. Cassell, Overstating America's Wrongful Conviction Rate? Reassessing the Conventional Wisdom About the Incidence of Wrongful Convictions (undated) (unpublished manuscript) (on file with Paul G. Cassell). I have not had time to read the manuscript but I offered comments to him for what I believe was an earlier draft of that manuscript. As with many of the issues raised by Professor Cassell, each is worthy of lengthy discussion. At this point, I will stand by what I wrote with a proviso that this issue might be visited at some point in the future.

77 See Richard Leo, Has the Innocence Movement Become an Exoneration Movement? The Risks and Rewards of Redefining Innocence, in WRONGFUL CONVICTIONS AND THE DNA Revolution: Twenty-Five Years of Freeing the InNOCEnt 57-83 (Daniel Medwed ed., 2017).

78 Marvin Zalman, Cautionary Notes on Commission Recommendations: A Public Policy Approach to Wrongful Convictions, 41 CRIM. L. BulL. 169 (2005).

79 D. Michael Risinger, Innocents Convicted, 97 J. CRIM. L. \& CRIMINOLOGY 761 (2007)

80 Perhaps substructuring can apply to different kinds of criminal convictions that have different wrongful conviction rates (which we cannot know and which might fluctuate). 
across jurisdictions." ${ }^{\prime 1}$

\section{Weighing COSTS OF WRONGFul CONVICTIONS}

In the first part of his reply, Professor Cassell joins in Dr. Laudan's cost-benefit analysis based on the Laudan and Allen observation that false negatives far outnumber wrongful convictions. "On this point I fully agree with him, and I doubt whether any of the other symposium participants dispute this point." No, none of the Symposium participants disagree with the numbers, but Professor Cassell entirely misses the point made by criminologists Brian Forst and Sean Bushway, ${ }^{82}$ law professor Michael Risinger, ${ }^{83}$ and $\mathrm{I}^{84}$ and we seem to be talking past each other on this point. The impunity experienced by those who get away with serious crimes is a mostly a result of upstream problems: crimes are hard to detect, many crimes are not reported, inept policing lets criminals get away, repressive policing discourages reporting, and the like. Professor Cassell's failure to understand (or express) the difference between apples and oranges and his willingness to join Dr. Laudan's ignorance about incapacitation research makes his weighing of the costs of crime less than useful.

\section{A. The Parole Extension Proposal ${ }^{85}$}

To "improve" on Laudan's proposal to lower the burden of proof in criminal trials, which is patently unconstitutional, Professor Cassell almost gleefully suggests that instead of lowering the burden of proof, any violent felony conviction carry a fixed "additional" ten-year parole term. It is ironic that this parole-officer-full-employment proposal is advanced in a portion of the Symposium focused on trade-offs, without a nod to the need for costbenefit analysis to determine if such a proposal makes criminological, social, fiscal, and actuarial sense. Professor Cassell simply assumes (or has been convinced) that Laudan and Allen's crime statistics analysis is valid. A critic might see a cognitive bias at work. ${ }^{86}$ I would offer a "liberal" amendment

81 NAT'L REgistry of EXONERATIONS, EXONERATIONS IN 20165 (Mar. 7, 2017), https://www.law.umich.edu/special/exoneration/Documents/Exonerations_in_2016.pdf.

82 See Brian Forst, Errors of Justice: Nature, Sources and Remedies 57-65 (2004); Shawn D. Bushway, Estimating Empirical Blackstone Ratios in Two Settings: Murder Cases and Hiring, 74 AlB. L. REv. 1087 (2011), reviewed in Zalman, supra note 1, at Part II C.1.

83 See D. Michael Risinger, Tragic Consequences of Deadly Dilemmas: A Response to Allen and Laudan, 40 Seton Hall L. Rev. 991 (2010).

84 Zalman, supra note 1, at Part II.B.3.

85 Cassell, Tradeoffs, supra note 5, at 1488-91.

86 A panel of twenty experienced directors of community corrections programs have called for slashing the numbers on parole by half. See COLUMBIA UNIVERSITY JUSTICE LAB, ToO Big To SucceEd: THE IMPACT OF THE GROWTH OF COMMUNITY CORRECTIONS AND WHAT Should Be Done ABout It (Jan. 29, 2018), http://justicelab.iserp.columbia.edu/img/Too_Bi 
and suggest that parole be accompanied with a panoply of social welfare support that would go a long way to reducing recidivism. One study found that civil rights awards of $\$ 500,000$ plus was associated with lower offending by exonerees. ${ }^{87}$ The Sentencing Project not long ago advocated an idea based on European practices, that no criminal penalty could exceed twenty years of imprisonment, but the law would allow longer imprisonment dependent on individualized review concluding that the prisoner has a continuing propensity for violence. ${ }^{88}$ To borrow from Jeff Foxworthy, if your immediate reaction is that this idea is preposterous, you might be a conservative. But if you like this idea, you might be a liberal.

\section{WHY IS THIS SUBJECT IMPORTANT?}

Gary Graham, executed in 2000 for a robbery murder based exclusively on fleeting eyewitness testimony was a messed up youth who did terrible things to people at the time he was arrested. There is a good chance that Graham was factually innocent of the crime for which he was executed. ${ }^{89}$ Was his moral worth as a human being relevant?

Throughout his writing, Professor Cassell points out the prior criminality of some exonerees and would factor a "moral" element into calculations of whether to value the harms of crime victims more than those wrongfully convicted. ${ }^{90}$ By the same metric, should we consider that some crime victims do not merit full sympathy because of their prior criminality and other personal immoralities and thereby seek to create a weaker crime prevention system because some victims do not deserve our full sympathy? My position is that policies addressing wrongful conviction should, by analogy with the defense attorneys not caring about the client's "actual" guilt, aim to create the most reliable system for the benefit of all in as neutral a way as possible.

When I began teaching a wrongful conviction class in 2003, aside from any issue of justice, it seemed clear that wrongful convictions have great emotive power, which in the real world of policy making could be a force mobilized to effect changes to a system, guarded by powerful political figures who are reflexively resistant to outside reform pressures. From this perspective, the prior criminality of exonerees should be irrelevant to policy

g_to_Succeed_Report_FINAL.pdf.

$8 \overline{7}$ Amy Shlosberg et al., Expungement and Post-Exoneration Offending, 104 J. CRIM. L. \& CRIMINOLOGY 353 (2014).

88 Marc Mauer, Minimzing the Maximum: Why Prison Sentences Should Be Capped at 20 Years, MARK NEws (Apr. 16, 2015), http://www.themarknews.com/2015/04/16/minimi zing-the-maximum-why-prison-sentences-should-be-capped-at-20-years/.

89 Capital Punishment in Context, The Case of Gary Graham: Post-Trial Period, https://capitalpunishmentincontext.org/cases/graham/posttrial (last visited Apr. 25, 2018).

90 Cassell, Tradeoffs, supra note 5, at 1478-79. 
makers. Of course, in the world of politics a "poster boy" exoneree like Kirk Bloodsworth influences people. ${ }^{91}$ However, as the goal of innocentrism is to create a more efficient, accurate, reliable and professional criminal justice system, not only to the benefit of the innocent but to the detriment of those who commit serious crimes, justice scholars need to focus on meaningful reforms. $^{92}$ This takes us back to the trade-offs asserted by the antiBlackstonians.

My article noted a disconnect between the legal or analytic scholarship of the anti-Blackstonians and social science research. I was concerned that some legal scholars advance criminal justice reforms without paying sufficient attention to data generated by research criminologists. ${ }^{93}$ I will leave it to readers to determine whether the Laudan and Allen analysis of trade-offs, endorsed by Professor Cassell, and criticized in The AntiBlackstonians, makes sense.

But my concern is that their focus on trial processes and constitutional decisions misses the larger picture of a very uneven, often deficient, and sometimes corrupt, criminal justice apparatus. ${ }^{94}$ Such faults may be overlooked by readers with cognitive biases that make criticism of "our" criminal justice system distasteful. Thus, when Professor Cassell suggests that my qualitative estimate of the incidence of false convictions "ultimately [] rests on little more than his own subjective sense of what the right figure is in this area," 95 he skips over my earlier attempt to use methods of national security estimations and my scan of descriptive literature that points to serious deficiencies in American criminal justice and my similar analysis in Part IV of The Anti-Blackstonians. ${ }^{96}$ Based on descriptive literature (i.e., qualitative research, law review articles, and serious investigative journalism) and analytic criminological research, it is my view that the American criminal justice system is deficient in many ways and in need of substantial reform. I worry that Professor Cassell's well-intentioned (but in my view deeply flawed) scholarship, will be used as ammunition by those in the law enforcement, forensic science, prosecutorial, and judicial communities who reflexively oppose necessary changes. As for concerns

91 Nancy Marion \& Marvin Zalman, Towards a Theory of Innocence Policy Reform, in CONTROVERSIES IN INNOCENCE CASES IN AMERICA 175-96 (Sarah Lucy Cooper ed., 2014).

92 Keith A. Findley, Toward a New Paradigm of Criminal Justice: How the Innocence Movement Merges Crime Control and Due Process, 41 Tex. TeCH L. REV. 133 (2008).

93 The lack of concern runs both ways; criminologists should pay more attention to legal scholarship.

94 I addressed this theme in an episodic fashion in Part IV of The Anti-Blackstonians. See supra note 1.

95 Cassell, Tradeoffs, supra note 5, at 1451.

96 Marvin Zalman, Qualitatively Estimating the Incidence of Wrongful Convictions, 48 CRIM. L. BULl. 221 (2012). 
about crime control expressed by Professors Cassell, Laudan, and Allen, I believe that the bulk of criminal justice research shows that the most effective methods of suppressing serious crime are either orthogonal to or (slightly) improved by innocence reform. The relatively small possibility of innocence reforms having an overall crime suppression effect is perhaps worthy of study, but not in the ways conducted by Professor Laudan or the other authors reviewed in The Anti-Blackstonians. Much of what has passed for crime deterrence in recent decades has probably done little to reduce crime and may have increased false convictions. The greater value of innocence movement reforms is in helping to create a more effective, accurate and fairer criminal justice process. 